\title{
Gastric Endocrine Cell \\ Carcinoma with Long-Term Survival Developing Metachronous Remnant Cancer
}

\author{
Tomoyuki Abe Naofumi Shigeta Yoshifumi Teraoka \\ Shoichiro Mukai Hiroshi Mitsuta Hidehiro Tanji \\ Shinya Kodama Kazuo Sumimoto \\ Department of Surgery, Yoshida General Hospital, Akitakata, Japan
}

\section{Key Words}

Endocrine cell carcinoma · Stomach · Long-term survival · Metachronous tumour

\begin{abstract}
A rare case of primary gastric endocrine cell carcinoma in a 79-year-old man is reported. Upper gastrointestinal endoscopy showed a large Bormann's type 2 tumour located in the middle of the stomach. On computed tomography, the gastric wall was thickened by the large tumour, and there were no distant metastases. Distal gastrectomy, lymph node dissection, and partial resection of the transverse colon were performed because the tumour involved the transverse mesocolon. The final pathological diagnosis was endocrine cell carcinoma, with tumour infiltration up to the subserous layer. Adjuvant chemotherapy was given, but metachronous remnant gastric cancer developed 2 years after surgery. Endoscopic submucosal dissection was performed for the early 0-llc type gastric cancer, and the surgical margin was preserved. The patient has survived for 5 years after the primary surgery, remaining disease-free so far.
\end{abstract}

\section{Introduction}

Neuroendocrine tumours (NETs) in the stomach, especially poorly differentiated ones, have a poor prognosis, since most cases are already in an advanced stage at the time of diagnosis. This type of NET must be treated like a normal gastric carcinoma, but three-quarters of patients die within 1 year of diagnosis due to extensive metastatic disease, and metachronous tumours develop in about 10\% during follow-up. Age, tumour size, depth, and location are significant predictors of metastases. However, there is no established adjuvant therapy. 
Here, a case of gastric endocrine cell carcinoma with long-term survival due to the combination of curative surgery, adjuvant chemotherapy, and early treatment of metachronous remnant gastric cancer is reported.

\section{Case Report}

A 79-year-old man presented in June 2004 with epigastric pain, weight loss, and vomiting. He had no previous diseases and was on no medications. He was $167 \mathrm{~cm}$ tall and weighed $53 \mathrm{~kg}$. Upper gastrointestinal endoscopy showed a large Bormann's type 2 tumour located in the middle body to the antrum of the stomach (fig. 1). Upper gastrointestinal radiographs showed that the gastric wall at the greater curvature from the body to the antrum was distorted irregularly by the tumour. On computed tomography, the gastric wall was thickened by the tumour (fig. 2). There were no metastatic lesions in the lungs, liver, or bones. Laboratory data included the following: white blood cell count 7,600/ $\mathrm{mm}^{3}$, haemoglobin $11.6 \mathrm{~g} / \mathrm{dl}$, platelets $315,000 / \mathrm{mm}^{3}$, and carcinoembryonic antigen increased to $114 \mathrm{ng} / \mathrm{ml}$. On laparotomy, distal gastrectomy and lymphadenectomy with partial resection of the transverse colon were undertaken because the tumour involved the transverse mesocolon. Operative time was $2 \mathrm{~h} 25 \mathrm{~min}$, with blood loss of $250 \mathrm{ml}$. The specimen showed an ulcerating large tumour $11.0 \times 5.5 \mathrm{~cm}$ in size. Microscopically, the tumour was composed of endocrine cells with dark round nuclei and scant cytoplasm stained with haematoxylin and eosin (fig. 3). Immunohistochemically, the tumour was positive for chromogranin and synaptophysin. The final pathological diagnosis was gastric endocrine cell carcinoma with microlymphovascular invasion.

Adjuvant chemotherapy consisting of S-1 and lentinan was given. Two years after surgery, upper gastrointestinal endoscopy showed an early type 0-IIC gastric cancer at the remnant stomach, and endoscopic submucosal dissection was performed. The pathological findings showed well-differentiated tubular adenocarcinoma. The tumour depth of the gastric wall was not beyond $500 \mu \mathrm{m}$, and the surgical margin was well preserved.

The patient has survived for 5 years after the surgery with adjuvant chemotherapy and successful resection of the metachronous early gastric cancer.

\section{Discussion}

Endocrine tumours of the gastrointestinal tract, first called carcinoids in 1907, are collectively termed NETs [1]. Primary gastric endocrine cell carcinoma is relatively rare and thought to account for $2-4 \%$ of all gastrointestinal NETs [2].

NETs in the stomach may be subdivided into different types. Some authors have divided them into three types: type 1 is associated with corpus-predominant atrophic gastritis, type 2 is associated with gastrinoma as part of MEN-1, and type 3 is the sporadic type of enterochromaffin-like cell carcinoid, as well as other types of neuroendocrine or mixed tumours with or without hormone production [3-5]. If the poorly differentiated NETs are added, four types of NETs can be distinguished [6, 7]. Type 1 accounts for approximately $70-80 \%$ of all cases, followed by type 3 as the next most frequent type, while type 2 and type 4 are rare [5].

The biologic behaviour and prognosis vary considerably by type. The prognosis of type 4 is frequently poor; the cumulative crude survival rate was only $33.3 \%$ at 5 years after diagnosis [8]. Some authors reported that the mean survival rates ranged from 6.5 to 14.9 months, and only about one-third of patients survived longer than 1 year $[9,10]$.

In general, there is no doubt that type 3 and type 4 should be treated aggressively with radical resection and lymph node dissection, because these types of tumours infiltrate 
beyond the submucosa more often than other types [8]. Even with curative surgery, liver metastases or lymph node recurrence occur frequently. The aggressive biological and clinical character of these types is similar to that of pulmonary small cell carcinoma, and some authors have proposed CDE chemotherapy (cisplatin, doxorubicin, and etoposide) or PE chemotherapy (cisplatin and etoposide) [11, 12]. Other treatment was based on adjuvant chemotherapy of the gastric cancer itself.

In our case, adjuvant chemotherapy with S-1 plus lentinan was given. Lentinan, a purified $\beta$-glucan, is a biological and immunological modifier that has been used as an anticancer drug in combination with 5-fluorouracil for gastric cancer in Japan. Oba et al. proposed that immunochemotherapy with lentinan has a synergistic effect, stimulating the immune system to reject and destroy tumours, especially advanced gastric cancer [13]. Though the efficacy of lentinan for gastric NETs is not established, we used it as adjuvant therapy, hoping for such a synergistic effect.

The main sites of recurrence are liver metastases or lymph node metastases, which are often impossible to resect surgically $[8,10]$. In case of type 3 or type 4 NETs, more careful follow-up must be undertaken to provide early detection and treatment of recurrence and metachronous tumours. Metachronous tumours develop in about $10 \%$ of cases during follow-up, and they usually occur within 4 years of the original tumours. Most tumours are adenomatous colonic polyps (26\%), followed by gastrointestinal carcinoma (21\%), urinary tract malignancy (19\%), and female reproductive organ malignancies (17\%) [14].

\section{Conclusion}

The case of a patient with a gastric endocrine cell carcinoma treated by curative resection, in whom a subsequent annual medical check-up resulted in the early detection and treatment of metachronous gastric remnant carcinoma, is presented. In this case, the careful follow-up may have contributed to the patient's long-term survival for 5 years.

\section{Disclosure Statement}

The authors had no financial and personal relationships with other people or organizations that might inappropriately influence (bias) this work. 


\begin{tabular}{c|l|l|l}
$\begin{array}{r}\text { Case Reports in } \\
\text { Gastroenterology }\end{array}$ & $\begin{array}{l}\text { Case Rep Gastroenterol 2011;5:117-121 } \\
\text { DOl: 10.1159/000326961 }\end{array}$ & $\begin{array}{l}\text { Published online: } \\
\text { April 6, 2011 }\end{array}$ & $\begin{array}{l}\text { O 2011 S. Karger AG, Basel } \\
\text { ISSN 1662-0631 } \\
\text { www.karger.com/crg }\end{array}$ \\
\hline
\end{tabular}

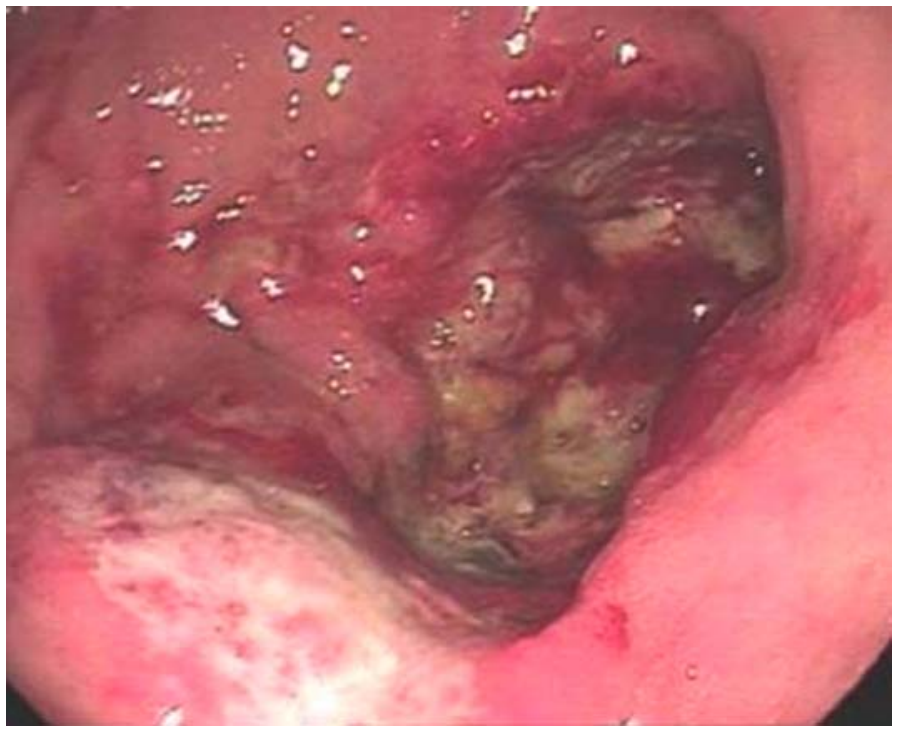

Fig. 1. Upper gastrointestinal endoscopy showing the massive Bormann's type 2 tumour located at the middle body of the stomach extending to the antrum.

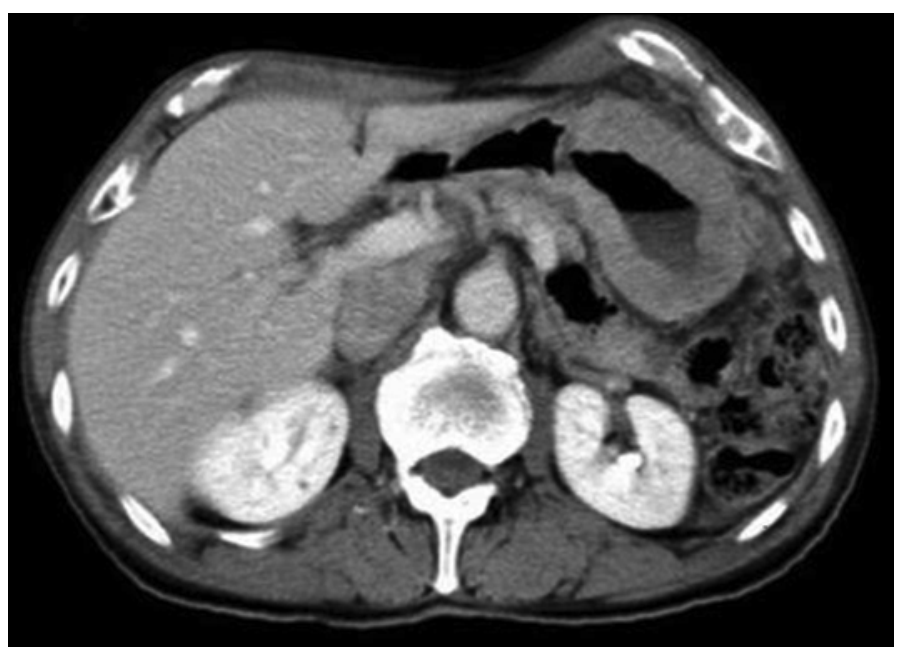

Fig. 2. Computed tomography showing that the tumour was detected as the thickness of the gastric wall. 


\begin{tabular}{c|l|l|l}
$\begin{array}{r}\text { Case Reports in } \\
\text { Gastroenterology }\end{array}$ & $\begin{array}{l}\text { Case Rep Gastroenterol 2011;5:117-121 } \\
\text { DOI: 10.1159/000326961 }\end{array}$ & $\begin{array}{l}\text { Published online: } \\
\text { April 6, 2011 }\end{array}$ & $\begin{array}{l}\text { @ 2011 S. Karger AG, Basel } \\
\text { ISSN 1662-0631 } \\
\text { www.karger.com/crg }\end{array}$ \\
\hline
\end{tabular}

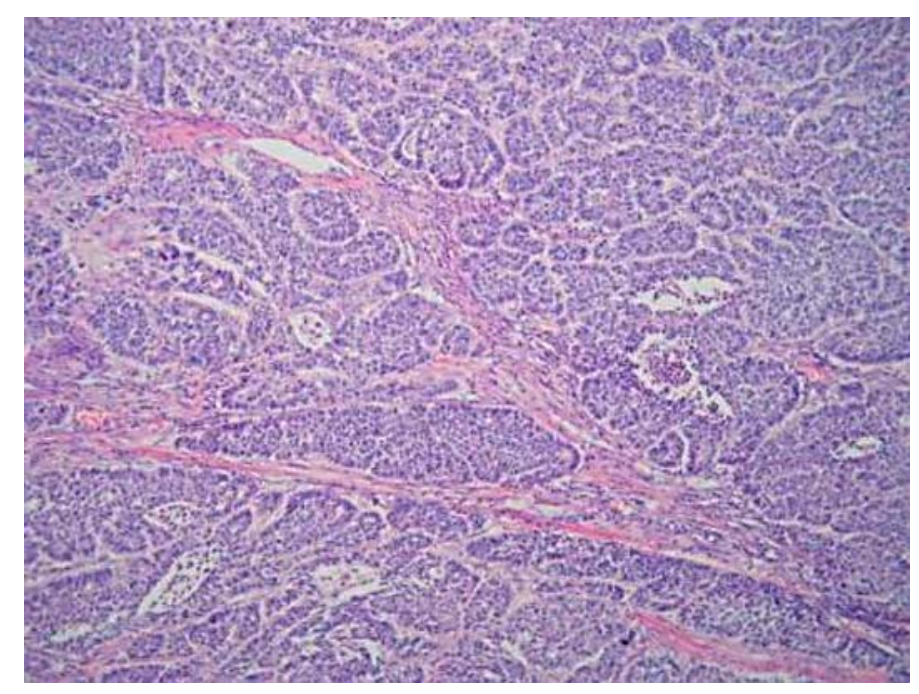

Fig. 3. The tumour was composed of endocrine cells with dark round nuclei and scant cytoplasm stained with haematoxylin and eosin $(\times 200)$.

\section{References}

1 Oberndorfer S: Karzinoide Tumoren des Dünndarms. Frankf Z Pathol 1907;1:7.

2 Modlin IM, Sandor A: An analysis of 8,305 cases of carcinoid tumors. Cancer 1997;79:813-829.

-3 Solcia E, Rindi G, Silimi E, et al: Enterochromaffin-like (ECL) cells and their growths: relationships to gastrin, reduced acid secretion and gastritis. Baillieres Clin Gastroenterol 1993;7:149-165.

4 Bordi C, Yu JY, Baggi MT, et al: Gastric carcinoids and their precursor lesions: a histologic and immunohistochemical study of 23 cases. Cancer 1991;67:663-672.

5 Rindi G, Luinetti O, Cornaggia $\mathrm{M}$, et al: Three subtypes of gastric argyrophil carcinoid and the gastric neuroendocrine carcinoma: a clinicopathologic study. Gastroenterology 1993;104:994-1006.

6 Ahlman H, Kobly L, Lundell L, et al: Clinical management of gastric carcinoid tumors. Digestion 1994;55(suppl 3):77-85.

7 Modlin IM, Kida M, Lye KD: Biology and management of gastric carcinoid tumours: a review. Eur J Surg 2003;168:669-683.

-8 Borch K, Ahrén B, Ahlman H, Falkmer S, Granérus G, Grimelius L: Gastric carcinoids: biologic behavior and prognosis after differentiated treatment in relation to type. Ann Surg 2005;242:64-73.

-9 Namikawa T, Kobayashi M, Okabayashi T, et al: Primary gastric small cell carcinoma: report of a case and review of the literature. Med Mol Morphol 2005;38:256-261.

10 Rindi G, Bordi C, Rappel S, La Rosa S, Stolte M, Solcia E: Gastric carcinoids and neuroendocrine carcinomas: pathogenesis, pathology, and behavior. World J Surg 1996;20:168-172.

11 Moertel CG, Kvols LK, O’Connell MJ, Rubin J: Treatment of neuroendocrine carcinomas with combined etoposide and cisplatin. Cancer 1991;68:227-232.

12 O'Byrne KJ, Cherukuri AK, Khan MI, et al: Extrapulmonary small cell gastric carcinoma. A case report and review of the literature. Acta Oncol 1997;36:78-80.

13 Oba K, Kobayashi M, Matsui T, Kodera Y, Sakamoto J: Individual patient based meta-analysis of lentinan for unresectable/recurrent gastric cancer. Anticancer Res 2009;29:2739-2746.

14 Shebani KO, Souba WW, Finkelstein DM, et al: Prognosis and survival in patients with gastrointestinal tract carcinoid tumors. Ann Surg 1999;6:815-823.

Written informed consent was obtained from our patient for publication of this case report and accompanying images. A copy of the written consent is available for review by the Editor-in-Chief of this journal on request. 